\title{
Some Biochemical and Morphological Characteristics of Serotypes of Verticillium albo-atrum from Hop
}

\author{
By SUDESH B. MOHAN* AND JON P. RIDE \\ Department of Microbiology, University of Birmingham, PO Box 363, Birmingham B15 2TT, UK
}

(Received 1 May 1984 ; revised 23 June 1984)

\begin{abstract}
Single-spore strains of Verticillium albo-atrum from hop, which had previously been classified into three serotypes by immunoelectrophoretic and immunofluorescence methods, have been further characterized using a series of morphological and biochemical parameters. Serotype 1 strains were characterized by high sporulation and low polygalacturonase activity when cultured on hop root cell walls, the presence of certain protein bands on isoelectric focusing of mycelial extracts, and a characteristic dark-pigmented mycelial morphology on prune/lactose/yeast extract agar. It is suggested that the expression of serotype 1 characteristics is controlled by the previously reported hyl ${ }^{+}$cytoplasmic factor. Serotypes 2 and 3 were both associated with low sporulation and high polygalacturonase activity and a fully hyaline fluffy mycelium, although many serotype 3 strains were only partially hyaline. Serotype 2 was associated with a characteristic pattern of mycelial proteins on isoelectric focusing gels: serotype 3 strains showed a heterogeneous series of patterns. None of the characters studied could be correlated with virulence for hop but the results do allow the selection for future studies of well-characterized strains which are extremely similar in many respects and yet still differ markedly in virulence.
\end{abstract}

\section{INTRODUCTION}

Verticillium albo-atrum infections of hop (Humulus lupulus) may result in either a fluctuating or a progressive type of vascular wilt attributable to mild (fluctuating) or more virulent (progressive) isolates of the fungus, respectively (Keyworth, 1942; Isaac \& Keyworth, 1948). At present, the virulence of field isolates can only be assessed by long-term pathogenicity tests (Talboys \& Wilson, 1954; Evans \& Framingham, 1979). In an attempt to evaluate serological tests as a possible aid in differentiating more rapidly between the two types of isolate, we recently reported two studies which described the analyses (from ten progressive and ten fluctuating isolates) of mycelial and culture filtrate antigens by immunoelectrophoretic methods (Mohan \& Ride, 1982) and of spore surface antigens by indirect fluorescent-antibody staining (Mohan \& Ride, 1983). Immunoelectrophoresis, using a cross-absorbed antiserum, detected an antigen, antigen ' 21 ', which was present in high concentrations in 12 isolates, and absent or present in low concentrations in the remaining 8 isolates. The fluorescent-antibody staining data divided the 20 isolates into two groups according to whether positive or negative fluorescence was obtained on spore surfaces with cross-absorbed antisera. A $90 \%$ correlation was found between the immunoelectrophoretic and fluorescent-staining methods. The antigens detected by these two methods were shown to be different and were used to define three serotypes for V. albo-atrum. An analysis of single-spore cultures from each of the 20 isolates by the two methods further substantiated the presence of the three serotypes: this study also revealed that the original isolates were antigenically mixed and that there was no correlation between serotypes and virulence of V. albo-atrum (Mohan \& Ride, 1983).

Abbreviations: PG, polygalacturonase; PLY, prune/lactose/yeast extract. 
It became apparent from the above reports that the true potential of serological methods for distinguishing between the two types of isolate could only be realized by studying strains which had as many antigens and other characters in common as possible and yet still differed in virulence. To achieve this objective, several morphological and biochemical characteristics of single-spore clones from the three serotypes were examined. An account of the parameters studied, their relevance in vascular wilt of hop and their significance in the serotype classification of $V$. albo-atrum strains, is reported in this paper.

\section{METHODS}

Organisms and media. Ten single-spore cultures from each of the five progressive (P6 to P10) and five fluctuating (F6 to F10) isolates of $V$. albo-atrum (Reinke \& Berthold) described previously (Mohan \& Ride, 1982; 1983) were used in this investigation. Serotype characteristics of these clones are listed in Table 1. Single-spore cultures from each isolate were numbered 1 to 10 ; for example, those from P6 were designated P6-1, P6-2, etc. to P6-10. Stock cultures were maintained on prune/lactose/yeast extract agar (PLY agar; Talboys, 1960) at $4{ }^{\circ} \mathrm{C}$.

Plating for single-spore colonies. Conidial suspensions were prepared and diluted in sterile water to give approximately 100 spores $\mathrm{ml}^{-1}$ as outlined previously (Mohan \& Ride, 1983). Samples $(0 \cdot 1 \mathrm{ml})$ of the dilute suspension were plated on the appropriate agar medium.

Preparation of mycelial extracts. These were prepared as described previously (Mohan \& Ride, 1982). The extracts were reconstituted to $5 \mathrm{mg}$ protein $\mathrm{ml}^{-1}$. Protein concentrations were determined by the Lowry method.

Preparation of hop root cell walls. Roots from hop plants (cultivar Early Bird) were washed in tap water, chopped, suspended in cold distilled water and homogenized for $1 \mathrm{~min}$ at top speed in a Sorvall Omni-mixer with the barrel immersed in ice. The homogenate was boiled for $15 \mathrm{~min}$, filtered through Whatman No. 1 filter paper using suction pressure and washed with water until the filtrate was colourless. The residue was soaked in ethanol for $1 \mathrm{~h}$, filtered and rinsed in ethanol as described above. This material, mainly cell walls, was further extracted twice with acetone and dried in vacuo over silica gel.

Rate of spore production. This was measured in shake cultures grown in $250 \mathrm{ml}$ conical flasks containing $100 \mathrm{ml}$ Vogel's medium (Vogel, 1956) and $2 \%(\mathrm{w} / \mathrm{v})$ sucrose or $0.2 \%(\mathrm{w} / \mathrm{v})$ hop root cell walls. Duplicate flasks were inoculated with conidial suspensions $\left(1 \mathrm{ml} ; 10^{4}\right.$ spores) and the cultures were initially grown statically at $15^{\circ} \mathrm{C}$ in dark for $2 \mathrm{~d}$, by which time mycelial growth was visible in most flasks containing sucrose. On day 3 , the cultures were shaken on a rotary shaker ( 100 r.p.m.) under the same conditions. After $1 \mathrm{~h}$ of shaking, samples $(5 \mathrm{ml})$ were withdrawn, filtered through four layers of muslin and the number of spores counted using a haemocytometer. Further samples were taken every $24 \mathrm{~h}$ for $8 \mathrm{~d}$.

Assay for polygalacturonase ( $P G ; E C$ 3.2.1.15) activity. The duplicate culture filtrate samples drawn for spore counts were pooled and centrifuged ( 4000 r.p. $\mathrm{m} ., 5 \mathrm{~min}$ ) to sediment spores. The clear supernatants were used to assay for total PG enzyme activity by estimating the increase in reducing groups as described by Miller (1959). The reaction mixture containing culture filtrate $(100-250 \mu \mathrm{l}$ made up to $500 \mu \mathrm{l}$ with distilled water) and polygalacturonic acid (Sigma, Grade II; $500 \mu 1 ; 0.5 \%$, w/v, in sodium acetate buffer, $0.2 \mathrm{M}, \mathrm{pH} 5.0$ ) was incubated at $30^{\circ} \mathrm{C}$ for $3 \mathrm{~h}$. Equivalent volumes of culture filtrates, boiled for $15 \mathrm{~min}$ and incubated as above with the substrate, were used as controls.

After incubation, samples (50-250 $\mu \mathrm{l}$ made up to $1.5 \mathrm{ml}$ with distilled water) were mixed with $1.5 \mathrm{ml}$ DNSA reagent (dinitrosalicylic acid, $5 \mathrm{~g}$; phenol, $1 \mathrm{~g}$; and sodium sulphite, $0.25 \mathrm{~g}$, dissolved in $500 \mathrm{ml}$ of $1 \%$, w/v, sodium hydroxide), heated for $15 \mathrm{~min}$ in a boiling water bath and cooled to room temperature. Potassium sodium tartrate $\left(0.5 \mathrm{ml} ; 40 \%\right.$, w/v, in distilled water) was then added and $A_{575}$ measured. Enzyme activity was expressed as $\mathrm{mg}$ galacturonic acid produced (ml extract) $)^{-1} \mathrm{~h}^{-1}$ using standards of galacturonic acid which were assayed in parallel.

Isoelectric focusing in agarose of mycelial extracts. The gels were cast and run as described in the leaflet 'Isoelectric Focusing, Principles and Methods' (Pharmacia). They contained agarose IEF (1\%, w/v; Pharmacia), sorbitol $(10 \%, \mathrm{w} / \mathrm{v})$ and carrier ampholytes $(3 \%, \mathrm{v} / \mathrm{v})$ in distilled water. For gels of $\mathrm{pH}$ range $2 \cdot 5-6 \cdot 5$, equal volumes of Pharmalytes $\mathrm{pH} 2.5-5$ and $\mathrm{pH}$ 4-6.5 (Pharmacia) were used, whereas the $\mathrm{pH}$ range 9-11 gels contained Ampholine $\mathrm{pH}$ 9-11 (LKB) and Pharmalyte $\mathrm{pH}$ 6.5-9 in the ratio 5:1. The cathode electrolyte for both gels was sodium hydroxide $(1 \mathrm{M})$; anode electrolytes were sulphuric acid $(0.05 \mathrm{M})$ and L-histidine $(0.2 \mathrm{M})$, respectively. Samples $(20 \mu \mathrm{l})$ were applied on paper sample applicators at the anode end of the gels. The gels were focused at $10^{\circ} \mathrm{C}$ for $1 \mathrm{~h}$ using an LKB Multiphor 2117 power pack at constant $15 \mathrm{~W}$, the power was then increased by $50 \%$ and the gels focused for a further $10 \mathrm{~min}$.

After the run, the gels were fixed for $1 \mathrm{~h}$ in trichloroacetic acid $(10 \%, \mathrm{w} / \mathrm{v})$ and sulphosalicylic acid $(5 \%, \mathrm{w} / \mathrm{v})$ in water and washed for $1 \mathrm{~h}$ under running water. The gels were press-dried, stained in Coomassie Blue R250 $(0.2 \%$, $\mathrm{w} / \mathrm{v})$ in ethanol/acetic acid/water (3.5:1:5.5, by vol.) overnight and then destained in dye-free solvent.

Isoelectric focusing of pectic enzymes. Eight-day-old culture filtrates from shake cultures, concentrated 10-fold over polyethylene glycol 6000 and dialysed against $0.1 \%$ glycine, were used to resolve the isoenzymic patterns of 
Table 1. Serotype characteristics of single-spore isolates of Verticillium albo-atrum used in this study

Patterns obtained with single-spore culture no.:

\begin{tabular}{|c|c|c|c|c|c|c|c|c|c|c|c|}
\hline \multirow{2}{*}{$\begin{array}{c}\text { Original } \\
\text { isolate }\end{array}$} & \multirow[b]{2}{*}{ Test* } & & & & & & & & & & \\
\hline & & 1 & 2 & 3 & 4 & 5 & 6 & 7 & 8 & 9 & 10 \\
\hline P6 & $\begin{array}{l}\text { FS } \\
\text { RLIE } \\
\text { Serotype }\end{array}$ & $\begin{array}{c}- \\
-1+ \\
3\end{array}$ & $\begin{array}{l}+ \\
+ \\
1\end{array}$ & $\begin{array}{l}+ \\
+ \\
1\end{array}$ & $\begin{array}{l}+ \\
+ \\
1\end{array}$ & $\begin{array}{l}+ \\
+ \\
1\end{array}$ & $\begin{array}{l}+ \\
+ \\
1\end{array}$ & $\begin{array}{l}+ \\
+ \\
1\end{array}$ & + & + & + \\
\hline P7 & $\begin{array}{l}\text { FS } \\
\text { RLIE } \\
\text { Serotype }\end{array}$ & $\begin{array}{l}+ \\
+ \\
1\end{array}$ & $\begin{array}{l}+ \\
+ \\
1\end{array}$ & $\begin{array}{l}+ \\
+ \\
1\end{array}$ & $\begin{array}{l}+ \\
+ \\
1\end{array}$ & $\begin{array}{l}+ \\
+ \\
1\end{array}$ & + & + & + & + & + \\
\hline P8 & $\begin{array}{l}\text { FS } \\
\text { RLIE } \\
\text { Serotype }\end{array}$ & - & $\frac{-}{2}$ & - & $\frac{-}{2}$ & $\frac{-}{2}$ & - & - & - & - & - \\
\hline P9 & FS & + & + & + & + & + & + & + & + & + & + \\
\hline P10 & $\begin{array}{l}\text { FS } \\
\text { RLIE } \\
\text { Serotype }\end{array}$ & $\begin{array}{l}+ \\
+ \\
1\end{array}$ & $\overline{-}$ & $\begin{array}{l}- \\
\overline{2}\end{array}$ & $\begin{array}{l}+ \\
+ \\
1\end{array}$ & $\begin{array}{l}+ \\
+ \\
1\end{array}$ & $\begin{array}{l}- \\
-\end{array}$ & $\begin{array}{l}- \\
\overline{2}\end{array}$ & $\frac{-}{2}$ & $\begin{array}{l}+ \\
+ \\
1\end{array}$ & $\begin{array}{l}- \\
\frac{2}{2}\end{array}$ \\
\hline F6 & $\begin{array}{l}\text { FS } \\
\text { RLIE } \\
\text { Serotype }\end{array}$ & $\begin{array}{l}+ \\
+ \\
1\end{array}$ & $\begin{array}{l}+ \\
+ \\
1\end{array}$ & $\overline{-}$ & $\overline{-}$ & $\frac{-}{2}$ & $\overline{-}$ & $\begin{array}{l}+ \\
+ \\
1\end{array}$ & $\begin{array}{l}+ \\
+ \\
1\end{array}$ & $\begin{array}{l}+ \\
+ \\
1\end{array}$ & $\begin{array}{l}+ \\
+ \\
1\end{array}$ \\
\hline F7 & $\begin{array}{l}\text { FS } \\
\text { RLIE } \\
\text { Serotype }\end{array}$ & $\frac{-}{2}$ & - & - & - & $\begin{array}{l}- \\
\overline{2}\end{array}$ & $\overline{-}$ & $\frac{-}{2}$ & - & - & - \\
\hline F8 & $\begin{array}{l}\text { FS } \\
\text { RLIE } \\
\text { Serotype }\end{array}$ & $-\overline{3}$ & - & - & - & $\begin{array}{l}- \\
+ \\
3\end{array}$ & $\begin{array}{l}- \\
+ \\
3\end{array}$ & - & - & - & $\begin{array}{l}- \\
+ \\
3\end{array}$ \\
\hline F9 & $\begin{array}{l}\text { FS } \\
\text { RLIE } \\
\text { Serotype }\end{array}$ & - & - & - & $\frac{-}{2}$ & $\frac{-}{2}$ & $\overline{-}$ & - & - & - & - \\
\hline $\mathrm{F} 10$ & $\begin{array}{l}\text { FS } \\
\text { RLIE } \\
\text { Serotype }\end{array}$ & $-\overline{3}+$ & - & - & - & $-1+$ & - & $\begin{array}{l}- \\
+ \\
3\end{array}$ & $-1+$ & - & - \\
\hline
\end{tabular}

* FS, fluorescent staining: +, bright green fluorescence around the spores; -, very dull or no fluorescence around the spores.

RLIE, rocket-line immunoelectrophoresis: + , antigen ' 21 ' present in high concentration; -, antigen ' 21 ' absent; $-1+$, antigen ' 21 ' present in low concentration.

Serotype: $V$. albo-atrum serotypes representing cultures which were 1, positive by FS and RLIE; 2, negative by FS and RLIE; 3, negative by FS, positive by RLIE.

endo-PG and pectate lyase (EC 4.2.2.2) enzymes. Isoelectric focusing in $1 \%$ agarose IEF and Ampholine pH 3.59.5 (LKB) was carried out as outlined above. The isoenzymes were identified as described by Lisker \& Retig (1974).

For PG isoenzymes, the focused gels were washed in citrate/phosphate buffer $(0.02 \mathrm{M}, \mathrm{pH} 5.0)$ for $5 \mathrm{~min}$, incubated with polygalacturonic acid $(1.2 \%, \mathrm{w} / \mathrm{v}$, in the above buffer) for $30 \mathrm{~min}$, washed with distilled water for $5 \mathrm{~min}$ and stained in Ruthenium Red solution $(0.05 \%, \mathrm{w} / \mathrm{v}$, in distilled water) for $30 \mathrm{~min}$. The stained gels were washed in water and press-dried. The pectate lyase isoenzymes were stained as above except that the gels were washed in Tris $/ \mathrm{HCl}$ buffer $(0.02 \mathrm{M}, \mathrm{pH} 8.3$ ) and incubated with pectin (Sigma, Grade I; $0.9 \%$, w/v, in Tris/HCl buffer containing $2 \mathrm{~mm}$-calcium chloride).

\section{RESULTS}

Variation in cultural morphology

(i) Mycelial colony types. Single-spore colonies were grown for each clone on PLY plates and incubated at either $15^{\circ} \mathrm{C}$ or $25^{\circ} \mathrm{C}$ to determine whether any variations observed in colony morphology could be related to the previous serotype classification. Two distinct mycelial colony types were observed at $15^{\circ} \mathrm{C}$ by day 3 (Fig. 1): Type A colonies were compact and had a white 

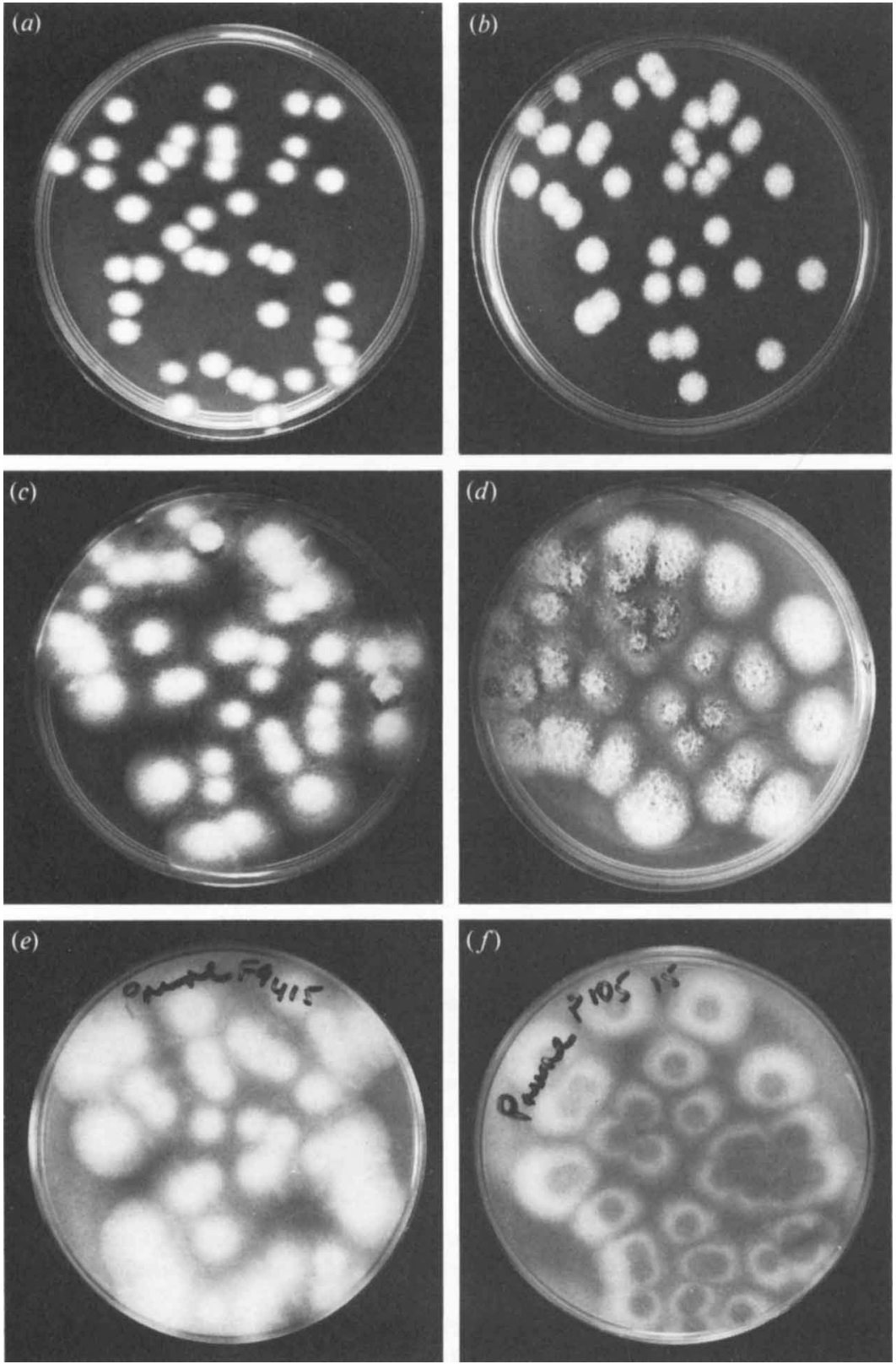

Fig. 1. Colony variations of V. albo-atrum grown on PLY agar at $15^{\circ} \mathrm{C}$. (a) and $(c): 3$ and 10 -d-old Type A colonies; $(b)$ and $(d): 3$ and 10-d-old Type B colonies; $(e)$ and $(f)$ : cultures $(c)$ and $(d)$ inverted to show hyaline and pigmented forms of Type A and Type B colonies, respectively.

fluffy surface appearance (Fig. 1a); in contrast, Type B colonies were slightly larger and less compact and fluffy than Type A colonies (Fig. $1 b$ ). These characteristic morphologies were retained as the colonies grew older (Fig. $1 c, d$ ). However, a dark brown pigment was produced by Type B colonies around day 5 and it darkened with the age of the culture (Fig. $1 f$ ): Type A colonies remained hyaline (Fig. 1e). Some clones of intermediate appearance were also observed, these (Type $\mathrm{C}$ colonies) had colonies with fluffy white mycelium and a slight hint of pigment production in older cultures ( $10 \mathrm{~d}$ or older), as judged by a faint circle of pigment at the 

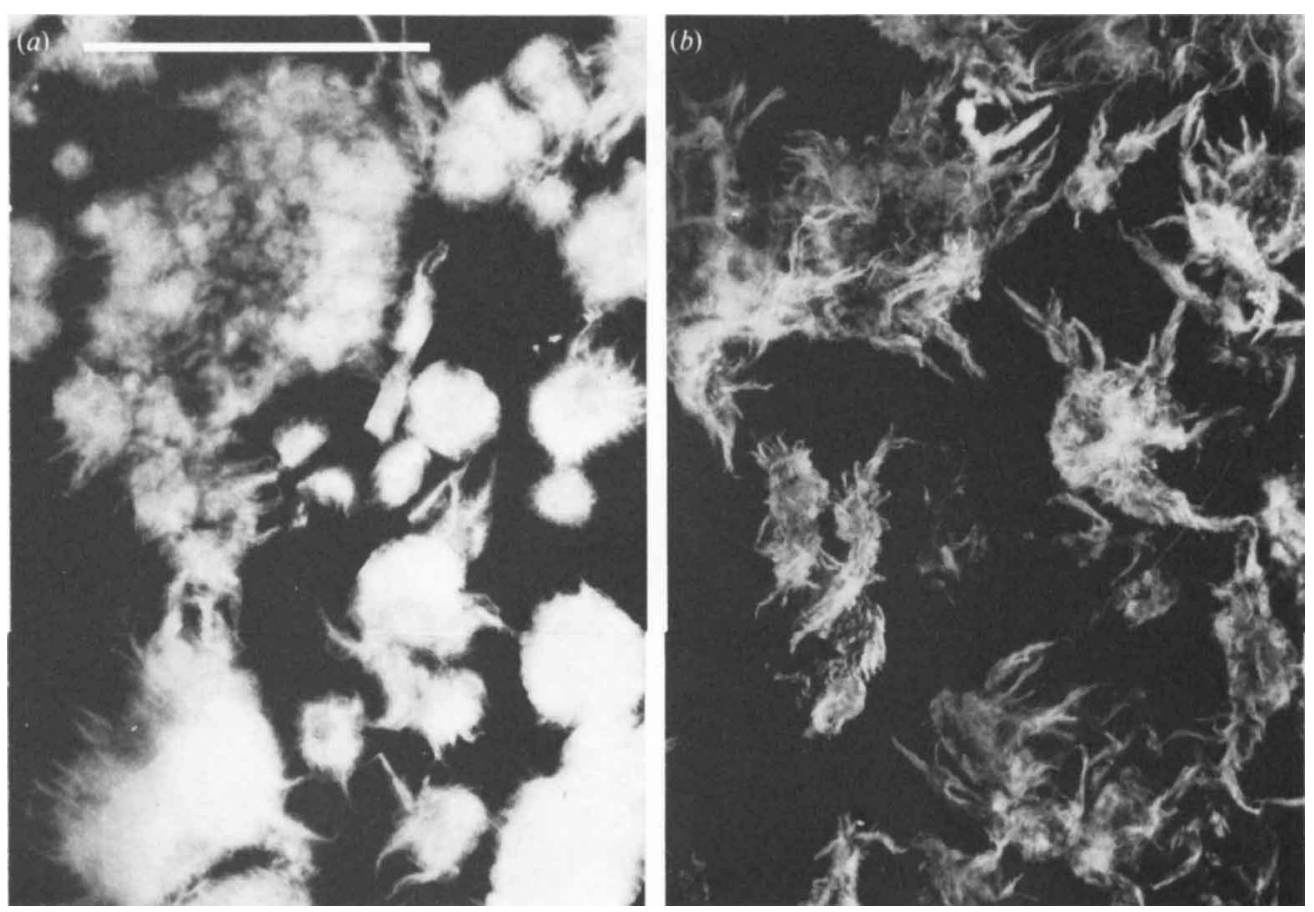

Fig. 2. Mycelial variations of $V$. albo-atrum grown on $2 \%(w / v)$ sucrose in shake cultures at $15^{\circ} \mathrm{C}$. (a) Type a culture showing clumps of fuffy mycelium; $(b)$ Type b culture with filamentous appearance. Bar marker, $1 \mathrm{~cm}$.

centre of the culture. Essentially similar patterns were obtained with cultures grown at $25^{\circ} \mathrm{C}$ : morphological variations were apparent in 3-d-old cultures but the pigment was produced much earlier than at $15^{\circ} \mathrm{C}$, most of the Type $\mathrm{B}$ colonies being dark by this time.

(ii) Characteristics of mycelium from shake cultures. Shake cultures grown in Vogel's medium containing $2 \%(\mathrm{w} / \mathrm{v})$ sucrose showed two distinct types of mycelial growth (Fig. 2): Type a, in which the mycelium formed tight clumps (Fig. $2 a$ ) so that clear liquid medium could be seen when the flasks were held against light; and Type $b$, in which the mycelium was flocculent and filamentous and the cultures appeared cloudy (Fig. $2 b$ ). No intermediate types were observed.

Table 2 compares the morphological features listed above in the clones tested. Clones which produced Type A mycelium on PLY agar also produced Type a cultures in liquid medium: all these were serotype 2 or serotype 3 clones. Conversely, Type B mycelium and Type b cultures were produced by all serotype 1 clones. Some serotype 3 clones produced Type $\mathrm{C}$ mycelium on PLY plates but had Type a liquid cultures. It appeared, therefore, that some specific morphological characteristics existed for each serotype of $V$. albo-atrum.

\section{Protein patterns of mycelial extracts by isoelectric focusing in agarose gels}

Mycelial proteins were resolved by isoelectric focusing in agarose gels to determine whether each serotype could be recognized by a specific protein pattern. Isolates F6 and P10 were antigenically the most mixed of the orginal 20 isolates (Table 1). The protein patterns obtained with mycelial extracts from the 10 single-spore cultures from each of these two isolates is shown in Fig. 3. Comparison of patterns in the $2 \cdot 5-6.5 \mathrm{pH}$ range gel (Fig. $3 a$ ) showed two distinct patterns. One pattern was produced by clones which contained one prominent band (I in Fig. $3 a$ ) and four bands of similar intensity in the anodic region of the gel (region II in Fig. $3 a$ ). This pattern was produced by all serotype 1 clones (F6-1, F6-2, F6-7 to F6-10, P10-1, P10-4, P10-5 and $\mathrm{P} 10-9)$. In the remaining clones, the band I was missing and one of the quartet in region II was more densely stained than the rest: all serotype 2 clones (F6-3 to F6-6, P10-2, P10-3, P10-6 to 
Table 2. Variation in cultural morphology obtained with single-spore cultures of $V$. albo-atrum isolates

\begin{tabular}{|c|c|c|c|c|c|c|c|c|c|c|c|}
\hline \multirow{2}{*}{$\begin{array}{l}\text { Original } \\
\text { isolate }\end{array}$} & \multirow{2}{*}{$\begin{array}{c}\text { Parameter } \\
\text { tested }\end{array}$} & \multicolumn{10}{|c|}{ Morphological form obtained with single-spore culture no.: } \\
\hline & & 1 & 2 & 3 & 4 & 5 & 6 & 7 & 8 & 9 & 10 \\
\hline P6 & $\begin{array}{l}\text { CT } \\
\text { Pigment } \\
\text { SCM } \\
\text { Serotype }\end{array}$ & $\begin{array}{l}\mathrm{C} \\
- \\
\mathrm{a} \\
3\end{array}$ & $\begin{array}{l}\text { B } \\
+ \\
b \\
1\end{array}$ & $\begin{array}{l}\text { B } \\
+ \\
b \\
1\end{array}$ & $\begin{array}{l}\text { B } \\
+ \\
\text { b } \\
1\end{array}$ & $\begin{array}{l}\text { B } \\
+\end{array}$ & $\begin{array}{l}\text { B } \\
+\end{array}$ & $\begin{array}{l}\text { B } \\
+\end{array}$ & $\begin{array}{l}\text { B } \\
+\end{array}$ & $\begin{array}{l}\text { B } \\
+\end{array}$ & $\begin{array}{l}\text { B } \\
+\end{array}$ \\
\hline P7 & $\begin{array}{l}\text { CT } \\
\text { Pigment } \\
\text { SCM } \\
\text { Serotype }\end{array}$ & $\begin{array}{l}\text { B } \\
+ \\
b \\
1\end{array}$ & $\begin{array}{l}\text { B } \\
+ \\
\text { b } \\
1\end{array}$ & $\begin{array}{l}\text { B } \\
+ \\
b \\
1\end{array}$ & $\begin{array}{l}\text { B } \\
+ \\
\text { b } \\
1\end{array}$ & $\begin{array}{l}\mathrm{B} \\
+ \\
\mathrm{b} \\
1\end{array}$ & $\begin{array}{l}\text { B } \\
+\end{array}$ & $\begin{array}{l}\text { B } \\
+\end{array}$ & $\begin{array}{l}\text { B } \\
+\end{array}$ & $\begin{array}{l}\text { B } \\
+\end{array}$ & $\begin{array}{l}\text { B } \\
+\end{array}$ \\
\hline P8 & $\begin{array}{l}\text { CT } \\
\text { Pigment } \\
\text { SCM }\end{array}$ & $\begin{array}{l}\mathrm{A} \\
- \\
\mathrm{ND}\end{array}$ & $\begin{array}{l}\text { A } \\
-\end{array}$ & $\begin{array}{l}\mathbf{A} \\
-\end{array}$ & $\stackrel{A}{-}$ & $\begin{array}{l}\mathbf{A} \\
-\end{array}$ & $\begin{array}{l}A \\
-\end{array}$ & $\begin{array}{l}\text { A } \\
-\end{array}$ & A & $\begin{array}{l}\text { A } \\
-\end{array}$ & $\begin{array}{l}\text { A } \\
-\end{array}$ \\
\hline P9 & $\begin{array}{l}\text { CT } \\
\text { Pigment } \\
\text { SCM }\end{array}$ & $\begin{array}{c}\text { B } \\
+ \\
\text { ND }\end{array}$ & $\begin{array}{l}\text { B } \\
+\end{array}$ & $\begin{array}{l}\text { B } \\
+\end{array}$ & $\begin{array}{l}\text { B } \\
+\end{array}$ & $\begin{array}{l}\text { B } \\
+\end{array}$ & $\begin{array}{l}\text { B } \\
+\end{array}$ & $\begin{array}{l}\text { B } \\
+\end{array}$ & $\begin{array}{l}\text { B } \\
+\end{array}$ & $\begin{array}{l}\text { B } \\
+\end{array}$ & $\begin{array}{l}\text { B } \\
+\end{array}$ \\
\hline P10 & $\begin{array}{l}\text { CT } \\
\text { Pigment } \\
\text { SCM } \\
\text { Serotype }\end{array}$ & $\begin{array}{l}\text { B } \\
+ \\
b \\
1\end{array}$ & $\begin{array}{l}\mathrm{A} \\
- \\
\mathrm{a} \\
2\end{array}$ & $\begin{array}{l}\text { A } \\
\bar{a} \\
2\end{array}$ & $\begin{array}{l}\text { B } \\
+ \\
\text { b } \\
1\end{array}$ & $\begin{array}{l}\mathrm{B} \\
+ \\
\mathrm{b} \\
1\end{array}$ & $\begin{array}{l}\text { A } \\
- \\
\mathrm{a} \\
2\end{array}$ & $\begin{array}{l}\text { A } \\
\bar{a} \\
2\end{array}$ & $\begin{array}{l}\text { A } \\
- \\
\mathrm{a} \\
2\end{array}$ & $\begin{array}{l}\mathrm{B} \\
+ \\
\mathrm{b} \\
1\end{array}$ & $\begin{array}{l}\text { A } \\
- \\
\mathrm{a} \\
2\end{array}$ \\
\hline F6 & $\begin{array}{l}\text { CT } \\
\text { Pigment } \\
\text { SCM } \\
\text { Serotype }\end{array}$ & $\begin{array}{l}\text { B } \\
+ \\
\text { b } \\
1\end{array}$ & $\begin{array}{l}\text { B } \\
+ \\
\text { b } \\
1\end{array}$ & $\begin{array}{l}\text { A } \\
- \\
a \\
2\end{array}$ & $\begin{array}{l}\mathrm{A} \\
- \\
\mathrm{a} \\
2\end{array}$ & $\begin{array}{l}\text { A } \\
- \\
a \\
2\end{array}$ & $\begin{array}{l}\text { A } \\
- \\
\text { a } \\
2\end{array}$ & $\begin{array}{l}\text { B } \\
+ \\
b \\
1\end{array}$ & $\begin{array}{l}\text { B } \\
+ \\
\text { b } \\
1\end{array}$ & $\begin{array}{l}\text { B } \\
+ \\
b \\
1\end{array}$ & $\begin{array}{l}\text { B } \\
+ \\
\text { b } \\
1\end{array}$ \\
\hline F7 & $\begin{array}{l}\text { CT } \\
\text { Pigment } \\
\text { SCM } \\
\text { Serotype }\end{array}$ & $\begin{array}{l}\mathrm{A} \\
- \\
\mathrm{a} \\
2\end{array}$ & $\begin{array}{l}A \\
-\end{array}$ & $\begin{array}{l}A \\
-\end{array}$ & $\stackrel{A}{-}$ & $\begin{array}{c}\text { A } \\
- \\
a \\
2\end{array}$ & $\begin{array}{l}\text { A } \\
- \\
\mathbf{a} \\
2\end{array}$ & $\begin{array}{l}\text { A } \\
- \\
\mathrm{a} \\
2\end{array}$ & $\begin{array}{l}\text { A } \\
-\end{array}$ & $\begin{array}{l}\text { A } \\
-\end{array}$ & $\begin{array}{l}\text { A } \\
-\end{array}$ \\
\hline F8 & $\begin{array}{l}\text { CT } \\
\text { Pigment } \\
\text { SCM } \\
\text { Serotype }\end{array}$ & $\begin{array}{c}C \\
-/+ \\
a \\
3\end{array}$ & $\begin{array}{l}A \\
-\end{array}$ & $\begin{array}{l}\mathbf{A} \\
-\end{array}$ & $\begin{array}{l}\text { A } \\
-\end{array}$ & $\begin{array}{l}\text { A } \\
- \\
\mathrm{a} \\
3\end{array}$ & $\begin{array}{l}\mathbf{A} \\
- \\
\mathbf{a} \\
\mathbf{3}\end{array}$ & $\stackrel{A}{-}$ & $\begin{array}{l}\text { A } \\
-\end{array}$ & A & $\begin{array}{c}\mathrm{C} \\
-/+ \\
\mathrm{a} \\
3\end{array}$ \\
\hline F9 & $\begin{array}{l}\text { CT } \\
\text { Pigment } \\
\text { SCM } \\
\text { Serotype }\end{array}$ & $\stackrel{A}{-}$ & $\begin{array}{l}A \\
-\end{array}$ & $\begin{array}{l}\text { A } \\
-\end{array}$ & $\begin{array}{l}\mathrm{A} \\
- \\
\mathrm{a} \\
2\end{array}$ & $\begin{array}{l}\mathrm{A} \\
- \\
\mathrm{a} \\
2\end{array}$ & $\begin{array}{l}\mathrm{A} \\
- \\
\mathbf{a} \\
2\end{array}$ & $\begin{array}{l}\text { A } \\
-\end{array}$ & $\begin{array}{l}\text { A } \\
-\end{array}$ & $\begin{array}{l}\text { A } \\
-\end{array}$ & $\begin{array}{l}\text { A } \\
-\end{array}$ \\
\hline F10 & $\begin{array}{l}\text { CT } \\
\text { Pigment } \\
\text { SCM } \\
\text { Serotype }\end{array}$ & $\begin{array}{l}\text { A } \\
\bar{a} \\
3\end{array}$ & $\begin{array}{l}\text { A } \\
-\end{array}$ & $\begin{array}{l}\mathbf{A} \\
-\end{array}$ & A & $\begin{array}{c}C \\
-/+ \\
a \\
3\end{array}$ & $\begin{array}{l}\text { A } \\
-\end{array}$ & $\begin{array}{c}C \\
-/+ \\
a \\
3\end{array}$ & $\begin{array}{l}\mathrm{A} \\
- \\
\mathrm{a} \\
3\end{array}$ & A & $\begin{array}{l}A \\
-\end{array}$ \\
\hline
\end{tabular}

ND, Not done.

* CT, colony type obtained on PLY agar plates: A, compact with fluffy white mycelium; B, less compact and fluffy; C, similar to B, except that older cultures produced dark pigments at the centre of the culture.

Pigment: + , dark brown pigment present in 5-d-old cultures; -, dark brown pigment absent in 5-d-old cultures; $-/+$, pigment produced in older cultures.

SCM, shake culture mycelium obtained in Vogel's medium containing $2 \%$ sucrose : a, compact mycelial clumps, $b$, filamentous.

Serotype: see Table 1.

P10-8 and P10-10) produced this pattern. Other differences were present between the tracks but these could not be correlated to the two serotypes. In the pH 9-11 gel, two distinct patterns were again observed (Fig. $3 b$ ). All serotype 1 clones produced two bands (III and IV in Fig, $3 b$ ): corresponding proteins in serotype 2 clones were generally more intensely stained. Furthermore, serotype 2 produced a third protein ( $\mathrm{V}$ in Fig. $3 b$ ) which appeared to be absent in serotype 1 clones.

Mycelial extracts from some clones of isolates P6, P7, F8, F9 and F10 were next resolved by 


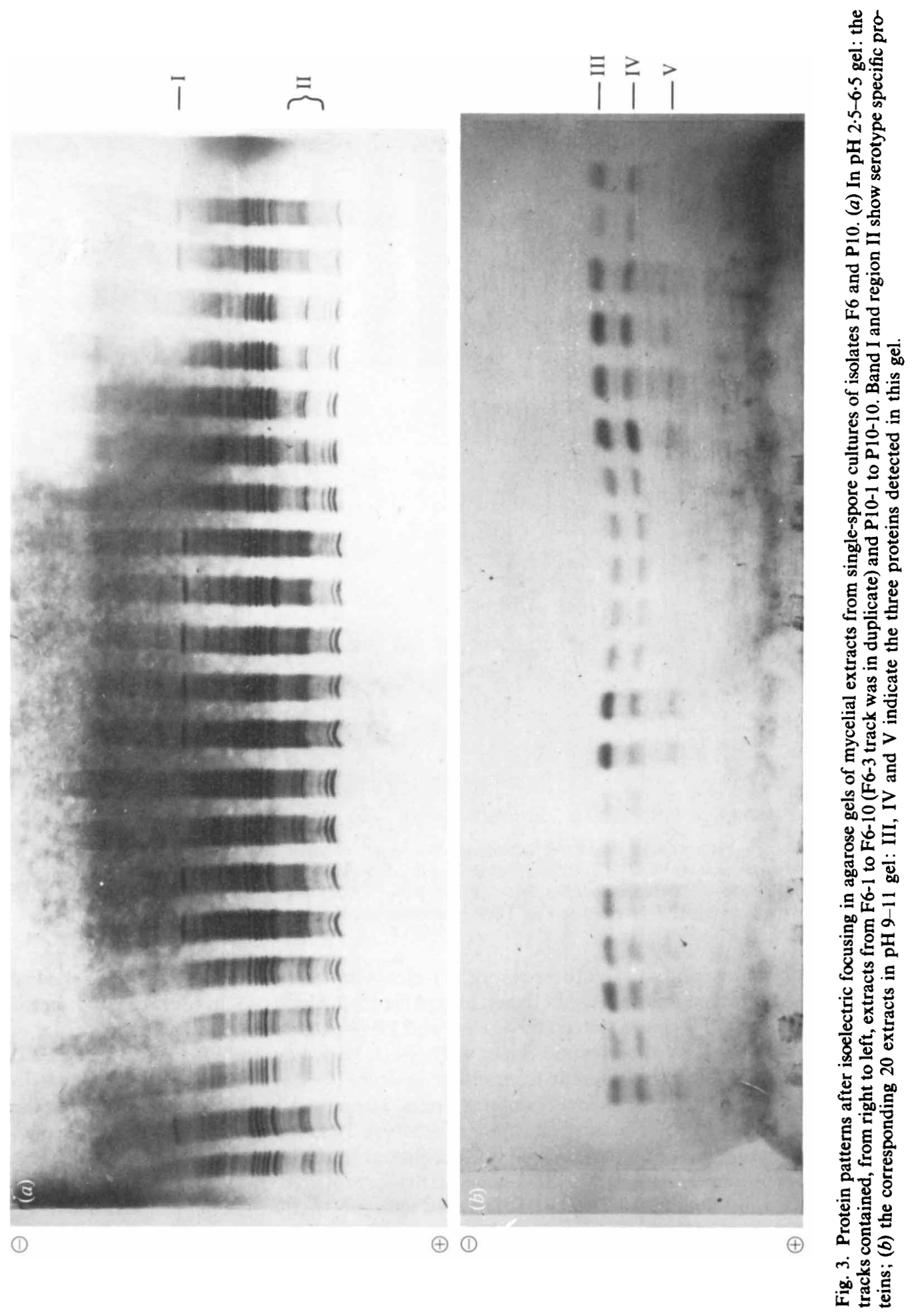




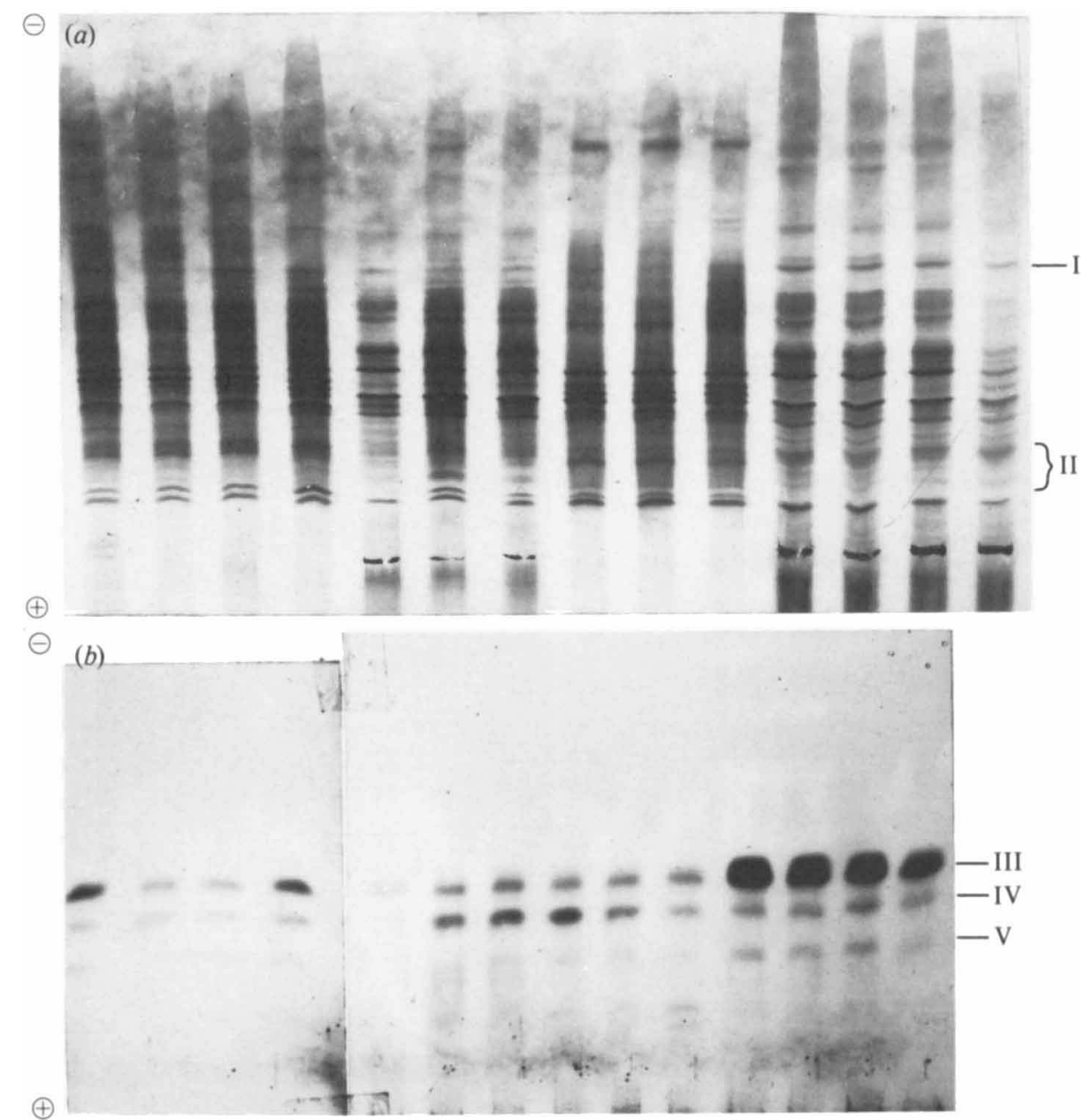

Fig. 4. Protein patterns after isoelectric focusing in agarose gels of mycelial extracts from some clones of V. albo-atrum isolates P6, P7, F8, F9 and F10. (a) In pH 2.5-6.5 gel: the tracks contained from right to left F8-1, F8-5, F8-6, F8-10, F9-4 to F9-6; F10-1, F10-5, F10-7, P6-1, P6-4, P7-1 and P7-2; (b) the corresponding extracts in $\mathrm{pH} 9-11$ gel. See Fig. 3 for explanation of $\mathrm{I}$ to $\mathrm{V}$.

isoelectric focusing (Fig. 4). The three serotype 1 clones tested (P6-4, P7-1 and P7-2) showed characteristic serotype 1 patterns in both gels except for P7-2 which produced three bands in the pH 9-11 gel. Three F9 clones tested (F9-4, F9-5 and F9-6) produced patterns characteristic of serotype 2 in both gels. With serotype 3 clones of F8 (F8-1, F8-5, F8-6 and F8-10) and F10 (F10-1, F10-5 and F10-7), patterns different from either serotype 1 or serotype 2 were obtained. In pH 2.5-6.5 gel (Fig. 4a), all F8 clones contained band I and the equally stained quartet but the rest of the patterns were different from those of serotype 1 clones. F10-7 resembled F8 clones where F10-1 and F10-5 had a pattern which was different from all the rest. In pH 9-11 gel (Fig. $4 b$ ) F8 clones produced three bands but the most cathodic protein (III, Fig. $4 b$ ) was very intensely stained; two F10 clones (F10-1 and F10-5) showed serotype 2 patterns in this gel, whereas $F 10-7$ patterns resembled serotype 1. P6-1, a serotype 3 clone, was different from F8 and F10 clones in that it formed patterns characteristic of serotype 1 in pH 2.5-6.5 gel and of serotype 2 in $\mathrm{pH} 9$ 11 gel. These patterns suggested that whereas serotypes 1 and 2 could be recognized by specific protein patterns, serotype 3 could not: this serotype perhaps consists of various subgroups. In none of the gels could any correlation be found between the protein patterns and virulence for hop. 

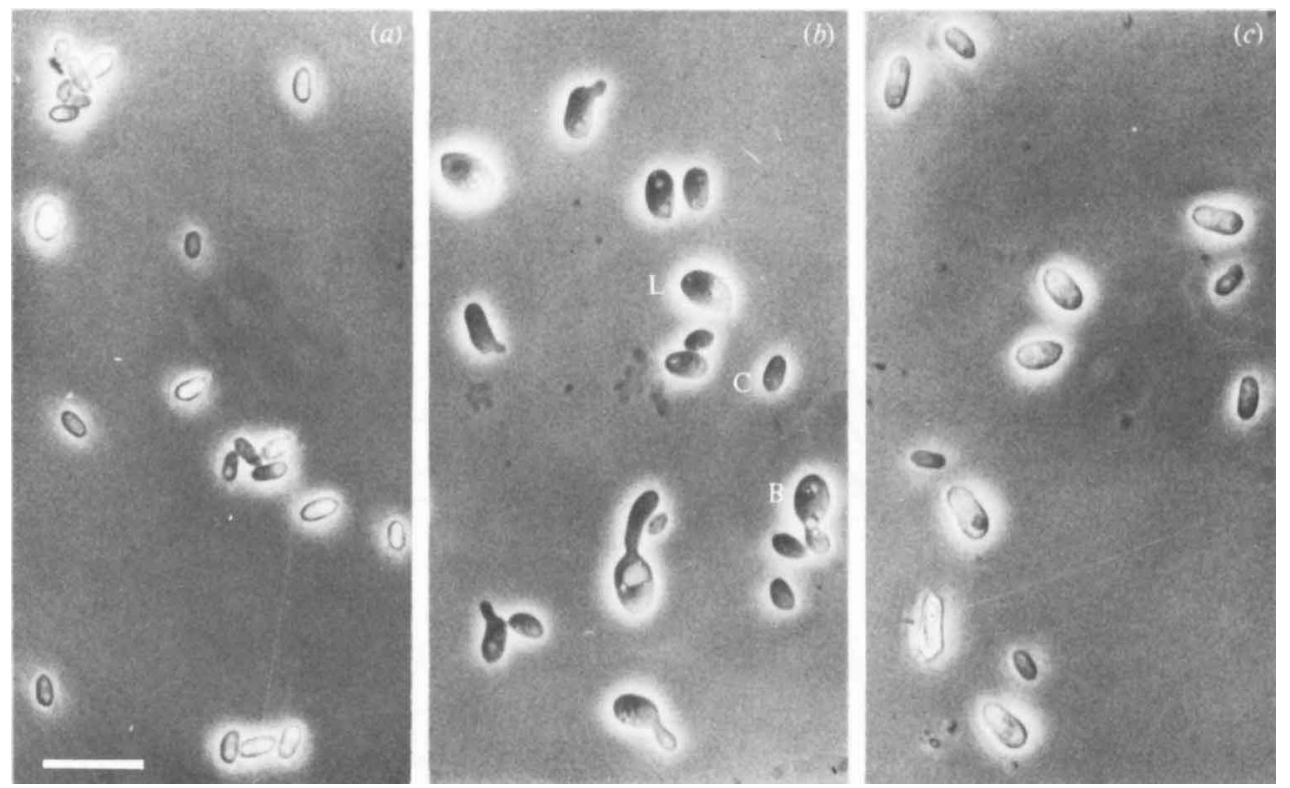

Fig. 5. Conidial variation of V. albo-atrum. (a) Normal conidia from 10-d-old PLY agar culture; $(b)$ yeast cells from 8 -d-old shake cultures grown on $2 \%(w / v)$ sucrose : B, C \& L show budding cells, normal conidia and large cells, respectively; $(c)$ conidia from 8 -d-old shake cultures grown on $0.2 \%(w / v)$ hop cell walls. Bar marker, $5 \mu \mathrm{m}$.

Comparison of single-spore cultures grown or sucrose or hop root cell walls

The data reported above and earlier (Mohan \& Ride, 1982, 1983) used V. albo-atrum cultures which were grown in Vogel's medium containing $2 \%$ sucrose. Though the fungus grew well on this medium and serotype distinctions could be made in the extracts prepared from these cultures, it was possible that the antigens resolved might not be those produced in an in vivo infection. It was feasible that growth of $V$. albo-atrum in medium containing hop root cell walls might induce the production of some in vivo antigens which might characterize the serotypes further. To test this possibility, some parameters of the following 12 clones were compared in media containing sucrose or hop root cell walls. Serotype 1: P6-4, F6-1, P7-1, P7-2, P10-1; serotype 2: F6-3, P10-3; serotype 3: P6-1, F8-1, F8-10, F10-5 and F10-7. All of these clones, except those derived from $\mathrm{P} 7$ isolate, had been tested at least once for virulence and their 'progressive' or 'fluctuating' status confirmed (Mohan \& Ride, 1983).

(i) Mycelial colony types on agar. Mycelial morphology of the twelve clones was compared at $15^{\circ} \mathrm{C}$ and $25^{\circ} \mathrm{C}$ on agar plates containing Vogel's medium and $2 \%(\mathrm{w} / \mathrm{v})$ sucrose or $0.2 \%(\mathrm{w} / \mathrm{v})$ cell walls. Clones grown for $8 \mathrm{~d}$ on sucrose produced colonies similar to those obtained on PLY agar described above, except that no pigment was produced in this medium. On hop cell walls, all clones produced spreading colonies and the pigment was again not produced: no distinction between serotypes could be made in this medium.

(ii) Conidial variations in shake cultures. Shake cultures of the 12 clones were grown in Vogel's medium containing sucrose or cell walls and the conidia produced in 8-d-old cultures examined. In sucrose, serotype 1 clones contained a heterogeneous assortment of single cells (Fig. $5 b$ ). Some of the cells were identical in appearance to conidia (compare normal conidia in Fig. $5 a$, and $\mathrm{C}$ in Fig. $5 b$ ), most cells were, however, yeast cells produced by a budding process (B in Fig. $5 b$ ) from large single cells ( $\mathrm{L}$ in Fig. $5 b$ ). Serotype 2 and 3 cultures did not contain any budding cells, though large and small cells were present. In contrast, cells from all cell wall grown cultures were either similar in size to normal conidia or larger, but the latter were smaller than those produced in sucrose (Fig. $5 c$ ). No budding cells were observed in these cultures. 

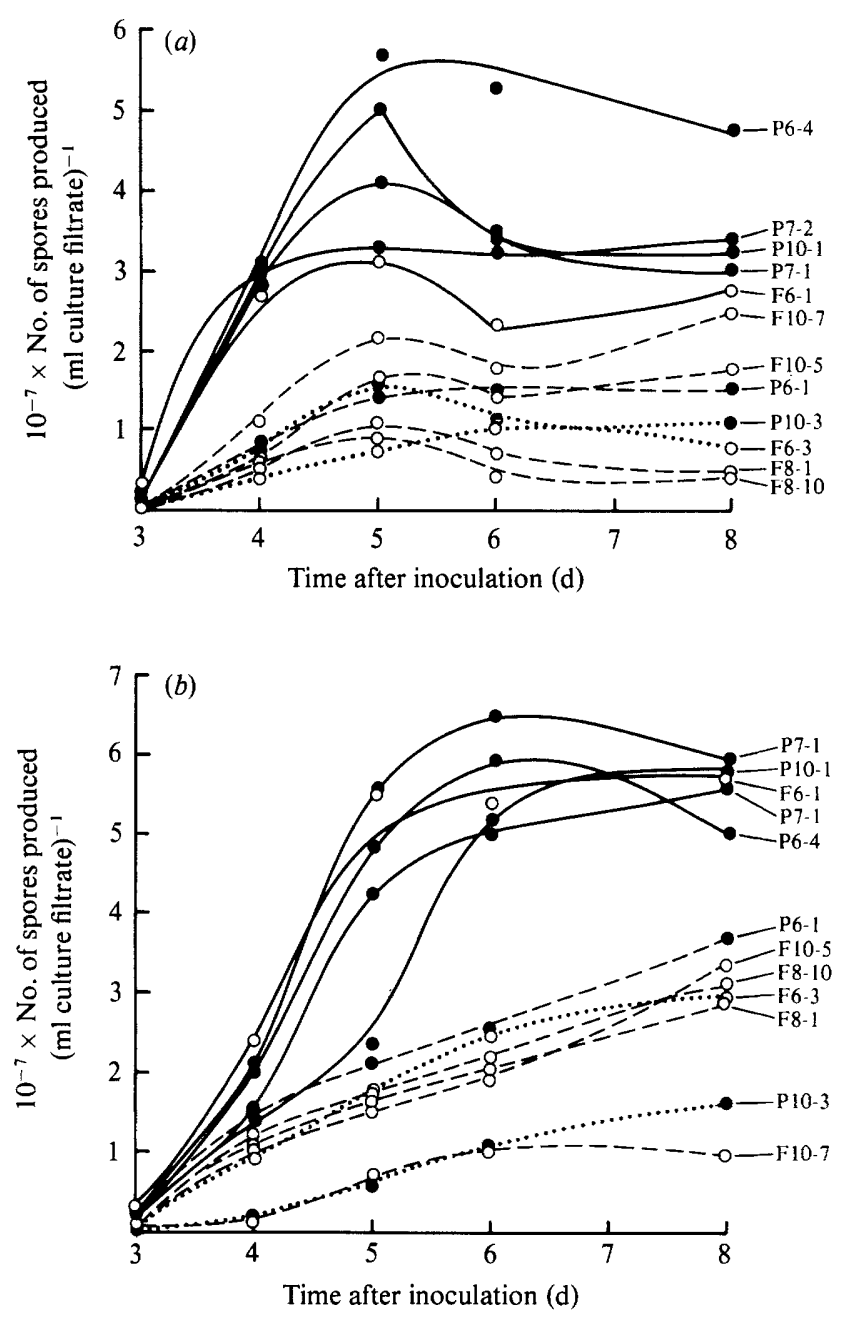

Fig. 6. Rate of spore production by single-spore cultures of V.albo-atrum: (a) on sucrose medium; (b) on hop root cell walls. Progressive and fluctuating clones of serotype $1(-)$, serotype $2(\cdots \cdots)$ and serotype $3(--)$ are shown by solid and open circles, respectively.

(iii) Rate of sporulation. The rates of spore production on the two media for the 12 clones tested are compared in Fig. 6 (for sucrose-grown cultures, all the heterogeneous cells were counted). Two distinct groups of high and low sporulation rate were obtained in both media, by day 4 on sucrose and day 6 on cell walls (Fig. $6 a$ and $b$, respectively). In both cases, all serotype 1 clones had high sporulation rates, serotypes 2 and 3 forming the low sporulation group. This distinction was still apparent in the cell wall medium on day 8 (Fig. $6 \mathrm{~b}$ ), but it was not so pronounced in sucrose medium (Fig. $6 a$ ). In the latter case, the rate of spore production in serotype 1 clones dropped slightly while that of the rest levelled off to give a continuous spectrum of sporulation rates. However, all serotype 1 clones were still on the top range of this spectrum.

(iv) Rate of PG production. PG activity could be detected in 4-d-old culture filtrates of all clones grown on media containing either sucrose or cell walls (Fig. 7). Each clone produced approximately three to four times more of this pectic enzyme on cell walls than on sucrose. Also, the level of enzyme activity was consistently higher in serotypes 2 and 3 clones than serotype 1 clones in both media. Comparison of the rate of PG production over $8 \mathrm{~d}$ showed two groups of high and low rate of enzyme production in cell wall grown cultures (Fig. $8 a$ ): these became more defined with the age of the cultures. All serotype 1 clones formed the low activity group whereas 


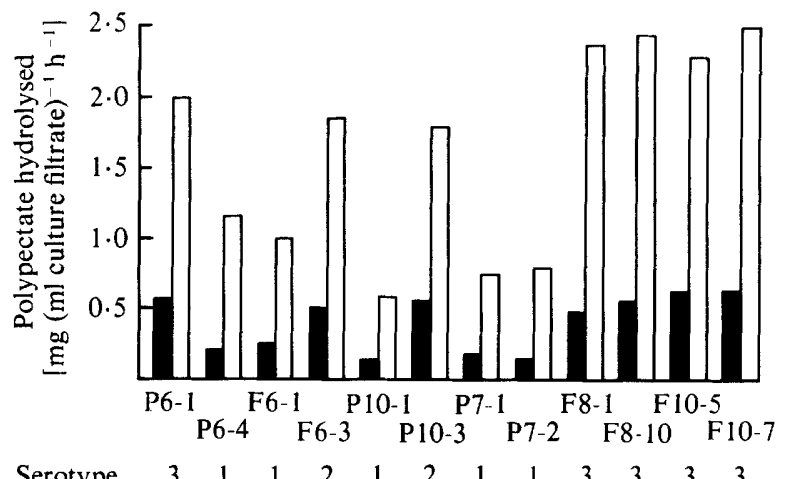

Fig. 7. Total PG activity of 4-d-old cultures of V. albo-atrum clones on sucrose medium ( $\square$ ) and on hop root cell walls $(\square)$.
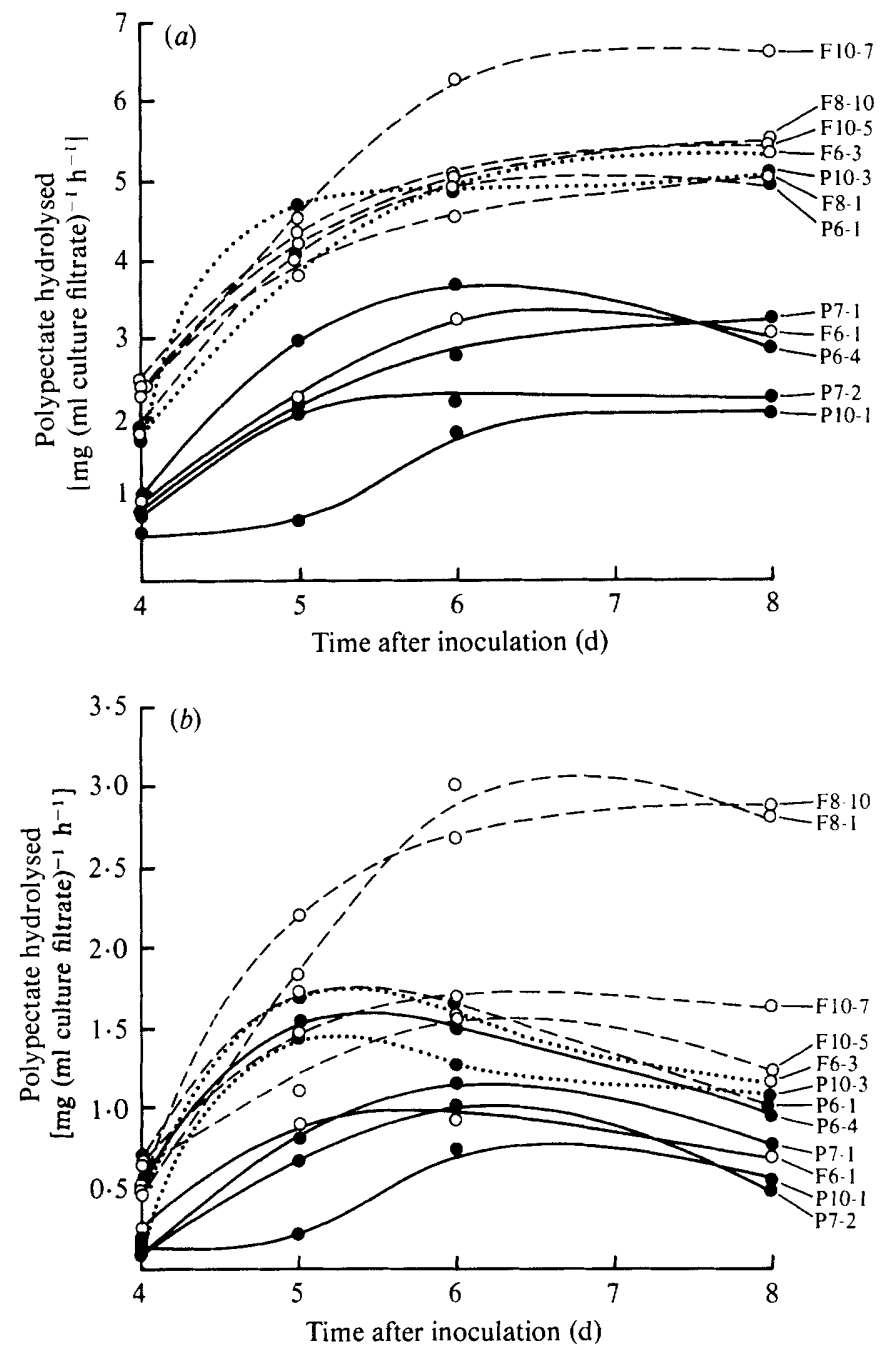

Fig. 8. Rate of total PG production by $V$. albo-atrum clones: $(a)$ on hop root cell walls; $(b)$ on sucrose medium. Progressive and fluctuating clones of serotype $1(-)$, serotype $2(\cdots \cdots)$ and serotype $3(---)$ are shown by solid and open circles, respectively. 


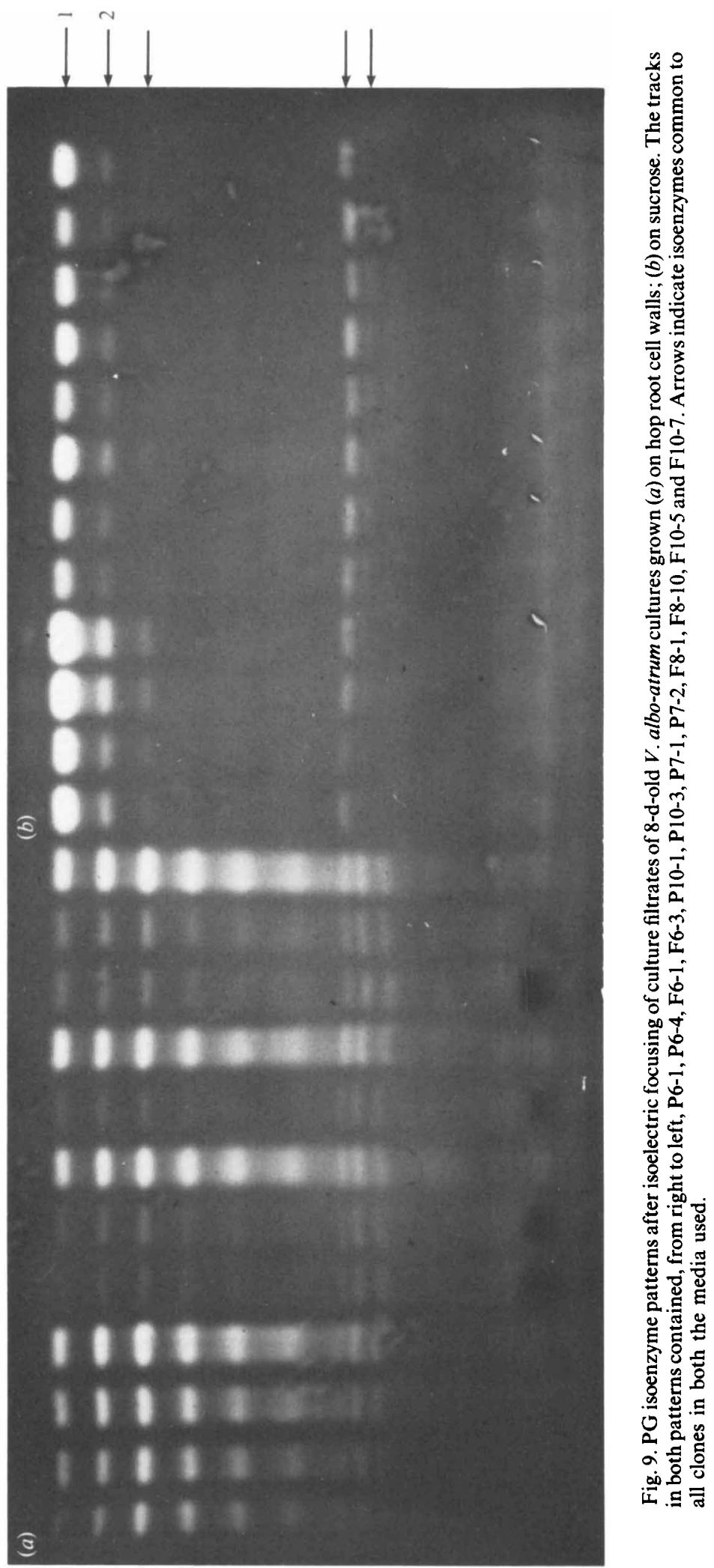




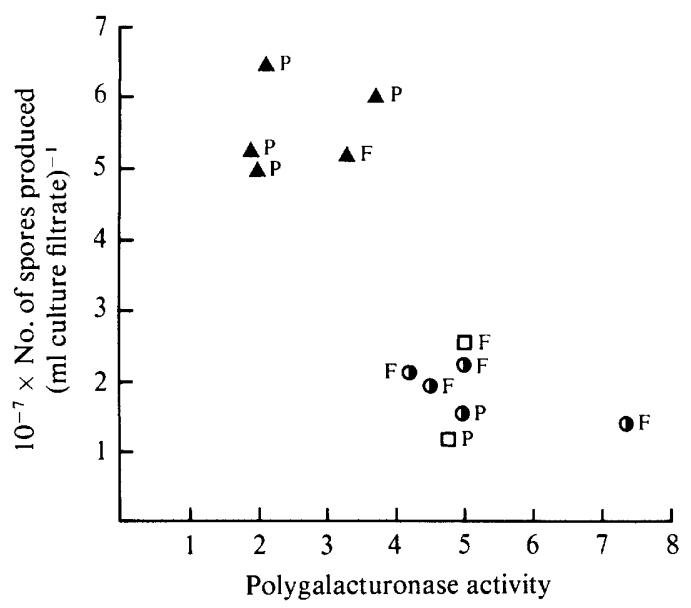

Fig. 10. Scatter diagram comparing the various characteristics of the three serotypes of V.albo-atrum. The data plotted for the number of spores $\mathrm{ml}^{-1}$ versus total $P G$ activity of progressive (P) and fluctuating $(F)$ clones of serotype $1(\triangle)$, serotype $2(\square)$ and serotype $3(O)$ are for 6 -d-old shake cultures grown on hop root cell wall medium (Figs $6 b$ and $8 a$, respectively). Type A hyaline, Type B pigmented and Type $\mathrm{C}$ partially hyaline morphologies are shown by open, closed and partially closed symbols, respectively. Enzyme activity was measured as $\mathrm{mg}$ polypectate hydrolysed ( $\mathrm{ml}$ culture filtrate $)^{-1} \mathrm{~h}^{-1}$.

serotypes 2 and 3 clones produced high enzyme levels. No such groups were apparent from the enzyme activity levels detected in the sucrose grown cultures (Fig. $8 b$ ) but serotype 1 clones occupied the lower activity range in the rates of enzyme production obtained; clones F8-1 and F8-10 had much higher enzyme activities than the rest.

(v) Pectic enzyme isoenzyme patterns. The rates of enzyme production described above were based on total hydrolytic activity attributable to both exo- and endo-enzymes. Plant pathogens frequently secrete a range of different pectic enzymes in culture (Cooper, 1983) some of which may be more important in pathogenesis than others. Isoelectric focusing in agarose was therefore used to resolve PG and pectate lyase isoenzymes in order to search for any serotype- or virulence-specific isoenzyme patterns. The detection method employed also has the advantage of being much more sensitive to endo- than exo-enzyme activity (Lisker \& Retig, 1974), the former are probably more important in pathogenicity (Cooper, 1983).

Five endo-PG isoenzymes were identified in cultures grown on sucrose (Fig. $9 b$ ) and most of these could be traced in all clones tested. Clones F8-1 and F8-10 contained higher amounts of the two cathodic isoenzymes ( 1 and 2 in Fig. $9 b$; as judged by the intensity and surface areas of these bands) compared to the remaining clones suggesting that the higher total activity observed for these clones (Fig. $8 b$ ) correlated with higher activities of these two isoenzymes. Nine isoenzymes were detected in all cell wall grown cultures (Fig. $9 a$ ), though the intensity of the bands varied; five of these were common to sucrose-grown cultures. All serotype 1 clones which showed low total PG activity had fainter isoenzyme bands than serotype 2 and 3 clones, suggesting that the variation in total activity observed between the serotypes (Fig. $8 a$ ) reflected quantitative changes in all isoenzymes rather than qualitative differences in isoenzyme patterns.

Pectate lyase activity could only just be detected in cultures grown on cell walls. One or possibly two faint anodic bands were visible in this medium while no bands at all were evident in the sucrose grown culture filtrates. No correlation between pectate lyase activity and serotypes could be distinguished. In sucrose medium, diffuse darker bands were obtained towards the cathode. These probably reflected pectin methylesterase activity (EC 3.1.1.11; Cruickshank \& Wade, 1980). Though one pectin methylesterase band was present for each clone, the areas of the bands varied, being smaller for all serotype 1 clones and larger for serotypes 2 and 3 , suggesting that the enzyme activity was lower in serotype 1 strains. This enzyme was not detected in cell wall medium. 


\section{DISCUSSION}

The data presented in this paper demonstrate that, in addition to the antigenic differences originally used to define the three serotypes, clones of $V$. albo-atrum show variations in other morphological and biochemical characters which correlate with serotype classification. Of the various parameters tested, resolution of mycelial proteins by isoelectric focusing showed perhaps the clearest distinction between the three serotypes (Figs 3 and 4). Protein patterns were specific for serotypes 1 and 2 but were variable (though different from serotypes 1 and 2) for serotype 3 clones. The lack of consistent serotype 3 protein patterns suggests that this group might consist of further sub-classes. No correlation could, however, be found between virulence and the presence, absence or intensity of any of the protein bands, even within a given serotype.

The rest of the parameters studied clearly distinguished serotype 1 from serotypes 2 and 3 , but did not always separate serotype 2 from serotype 3 . Thus all serotype 1 cultures produced dark pigmented Type B morphology on PLY agar and Type b mycelium in shake cultures (Figs 1 and 2, Table 2): hyaline Type A mycelium on PLY agar and Type a mycelium in shake culture were characteristic of serotype 2 . Most serotype 3 clones produced partially hyaline Type $C$ mycelium on agar and Type a in shake culture, although several had fully hyaline characteristics of serotype 2. Also, high rates of sporulation and low rates of PG production were a feature of all serotype 1 cultures (Figs 6,7 and 8 ) whereas serotypes 2 and 3 formed one group which showed low sporulation rates and high pectic enzyme levels. These data, summarized in Fig. 10, suggest that serotypes 2 and 3 are more closely related to each other than to serotype 1 .

The general correlation of pigmentation with serotype is interesting in that the formation of pigment is known to be associated with the development of resting mycelium and to be principally under the control of a cytoplasmic factor, hyl ${ }^{+}$(Typas \& Heale, 1976, 1979), although chromosomal genes can have an influence (Hastie, 1968). Hyaline or partially hyaline strains may lack the cytoplasmic factor or contain it in a different form, hyl, and can be generated spontaneously from dark parental strains at frequencies varying from 1 in $10^{3}$ to 1 in $10^{6}$ (Typas \& Heale, 1976). This raises the possibility that the expression of serotype 1 associated characters (high sporulation, low PG activity, Type B mycelium on agar, Type b mycelium in shake cultures and the presence of certain protein bands on isoelectric focusing gels) might also be associated with $\mathrm{hyl}^{+}$factor. One prediction from this would be that since serotype does not correlate with virulence (Mohan \& Ride, 1983), then pigmentation, if controlled by the same factor, would not either. This is indeed the case in this study (Fig. 10). Furthermore, Harris (1961) has reported that hyaline variants of a progressive isolate of $V$. albo-atrum from hop are not different in virulence from the dark pigmented forms: our data also substantiate this observation (Fig. 10). Another prediction would be that serotype 1 isolates should spontaneously and irreversibly convert at a low frequency to serotype 2 or 3 . This has not been observed with our isolates probably because sufficient single-spore subcultures have not yet been made. However, no reversion of hyaline strains to pigmented strains has been documented in the literature, suggesting that our prediction is probably correct.

Comparison of cultures grown on sucrose and hop root cell walls illustrated the importance of the choice of medium used for studying $V$. albo-atrum serotypes. Serotype 1 could be clearly distinguished from serotypes 2 and 3 on the cell wall medium on the basis of rates of spore and PG production (Figs $6 b, 7$ and $8 a$ ): these distinctions were maintained over the $8 \mathrm{~d}$ period the experiments were conducted. Though a segregation of clones into two groups of low and high sporulation rates was observed initially in sucrose medium (Fig. $6 a$ ), these were not reflected in older cultures and no such patterns were obtained for pectic enzyme levels (Fig. 8b). Five endo-PG isoenzymes were detected in sucrose medium, as compared to nine in hop cell wall medium, suggesting that four of the nine isoenzymes were induced by the cell walls. It is possible, therefore, that cell wall medium might induce the synthesis of more proteins which have not been detected in the present study, and that immunological analysis of antigens from clones grown in this medium might prove useful in distinguishing between progressive and fluctuating isolates of V. albo-atrum.

The observation that progressive and fluctuating isolates within a serotype showed similar rates of sporulation and $\mathrm{PG}$ production suggested that these parameters are probably not asso- 
ciated with the virulence of $V$.albo-atrum. The spread of V.albo-atrum within hop plants is due to the dispersal of conidia in the xylem sap (Sewell \& Wilson, 1964). Also, the virulence of Verticillium for cotton has been correlated with a high rate of sporulation (Schnathorst, 1963; Bell, 1969). It was conceivable, therefore, that rates of sporulation, and hence colonization, by the fungus might distinguish between progressive and fluctuating strains. No support for this possibility was evident from the present study: both progressive and fluctuating strains were found in the high sporulation group (serotype 1) and also in the low sporulation group (serotype 2/3; Fig. 6). So, unless some other factors exist in in vivo situations to control the spread of the fungus, our results suggest that sporulation rate is not a major factor in determining virulence of $V$. alboatrum in hop.

Pectic enzymes have been implicated in the pathogenesis of Verticillium, though some evidence to the contrary has also been published (Pegg, 1981). Talboys \& Busch (1970) studied 23 isolates of $V$. albo-atrum from hop and found no close correlation between enzyme production and virulence, but somewhat higher levels appeared to be associated with virulence. In the present study, rates of PG production were serotype specific regardless of the 'progressive' or 'fluctuating' status of the clones tested (Fig. 8). The enzyme assay used detected both exo- and endoPG activity but the general intensity of bands detected by ruthenium red staining of gels (Fig. 9) suggests that the assay gave a good reflection of the potentially more important endo activity. PGs from V. albo-atrum may in any case have a dual endo-exo action (Cooper et al., 1978). Only very low pectate lyase activity could be detected and this enzyme was not investigated further. It appears, therefore, that pectic enzyme patterns do not distinguish between progressive and fluctuating strains of $V$. albo-atrum. Nevertheless it is possible that in the living host the production, secretion or the activity of the enzymes is influenced in a way which is not reflected in the in vitro conditions used here. Alternatively, perhaps a certain minimum activity is required for pathogenicity, but differences in virulence between strains are controlled by other, as yet unknown, factors.

Although none of the parameters studied here allow us to distinguish between progressive and fluctuating strains of $V$. albo-atrum, it is now possible to select single-spore strains which are extremely similar in many respects and yet differ markedly in virulence for hop. Analysis by immunological techniques of the in vivo and in vitro antigens of these selected strains is now being undertaken in the hope that 'progressive' or 'fluctuating' markers will be easier to detect than when a more heterogeneous group of strains was used (Mohan \& Ride, 1982, 1983). In addition, future studies on virulence mechanisms in $V$. albo-atrum must take into account the possibility that serotype, spore production and PG activity are all probably influenced by the hyl ${ }^{+}$ cytoplasmic factor, and that conversion from serotype 1 to serotypes 2 and 3 could occur during the course of an experiment and result in a dramatic change in many characteristics of the isolate, even if not in virulence. The possibility that such a conversion could occur in the infected host is also intriguing.

The authors are grateful to the Ministry of Agriculture, Fisheries and Food for financial support.

\section{REFERENCES}

Bell, A. A. (1969). Phytoalexin production and Verticillium resistance in cotton. Phytopathology 59, 1119-1127.

CoOper, R. M. (1983). The mechanisms and significance of enzymic degradation of host cell walls by parasites. In Biochemical Plant Pathology, pp. 101135. Edited by J. A. Callow. Chichester, UK : John Wiley \& Sons.

CoOper, R. M., Rankin, B. \& Wood, R. K. S. (1978). Cell wall-degrading enzymes of vascular wilt fungi. 11. Properties and modes of action of polysaccharides of Verticillium a!bo-itrum and Fusarium oxysporum f.sp. lycopersici. Physiological Plant Pathology 13, $101-134$.
Cruickshank, R. H. \& Wade, G. C. (1980). Detection of pectic enzymes in pectin-acrylamide gels. Analytical Biochemistry 107, 177-181.

Evans, E. J. \& Framingham, E. E. (1979). Method of determining strain pathogenicity of Verticillium alboatrum wilt of hops. Technical Bulletin, Ministry of Agriculture, Fisheries and Food, South Eastern Region.

HARRIS, R. V. (1961). Progress in research on Verticillium wilt and virus diseases of hops in 1960. Report East Malling Research Station for 1960, pp. 141-144.

Hastie, A. C. (1968). Phialide analysis of mitotic recombination in Verticillium. Molecular and General Genetics 102, 232-240. 
ISAAC, I. \& KEYWORTH, W. G. (1948). Verticillium wilt of hop (Humulus lupulus). III. A study of the pathogenicity of isolates from fluctuating and from progressive outbreaks. Annals of Applied Biology 35 , 243-249.

KEYWORTH, W. G. (1942). Verticillium wilt of the hop (Humulus lupulus). Annals of Applied Biology 29, 346357.

LISKER, N. \& RETIG, N. (1974). Detection of polygalacturonase and pectin lyase isoenzymes in polyacrylamide gels. Journal of Chromatography 96, 245-249.

Miller, G. L. (1959). Use of dinitrosalicylic acid reagent for determination of reducing sugar. Analytical Chemistry 31, 426-428.

Mohan, S. B. \& Ride, J. P. (1982). An immunoelectrophoretic approach to the identification of progressive and fluctuating isolates of the hop wilt fungus Verticillium albo-atrum. Journal of General Microbiology 128, 255-265.

MoHAN, S. B. \& Ride, J. P. (1983). Fluorescentantibody staining of conidia of isolates of Verticillium albo-atrum in relation to their virulence for hop. Journal of General Microbiology 129, 3581-3589.

PEGG, G. F. (1981). Biochemistry and physiology of pathogenesis. In Fungal Wilt Diseases of Plants, pp. 193-253. Edited by M. E. Mace, A. A. Bell \& C. H, Beckman. New York: Academic Press.
SCHNATHORST, W. C. (1963). Theoretical relationships between inoculum potential and disease severity based on a study of the variation in virulence among isolates of Verticillium albo-atrum. Phytopathology $\mathbf{5 3}$, 888.

Sewell, G. F. W. \& Wilson, J. F. (1964). The occurrence and dispersal of Verticillium conidia in xylem sap of the hop (Humulus lupulus). Nature, London 204, 901.

TALBOYS, P. W. (1960). A culture medium aiding the identification of Verticillium albo-atrum and $V$. dahliae. Plant Pathology 9, 57-58.

TalboYs, P. W. \& BusCH, L. V. (1970). Pectic enzymes produced by Verticillium species. Transactions of the British Mycological Society 55, 367-381.

Talboys, P. W. \& WILSON, J. F. (1954). A method for determining the pathogenicity of strains of Verticillium albo-atrum isolates from hop. Report East Malling Research Station for 1953, 158-161.

Typas, M. A. \& Heale, J. B. (1976). Heterokaryosis and the role of cytoplasmic inheritance in dark resting structure formation in Verticillium species. Molecular and General Genetics 146, 17-26.

Typas, M. A. \& Heale, J. B. (1979). Transfer of a cytoplasmic factor by micro-injection in Verticillium. Journal of General Microbiology 111, 375-386.

VoGEL, H. J. (1956). A convenient growth medium for Neurospora. Microbial Genetics Bulletin 13, 42-43. 